\title{
Partisan Journalists on Duty: Political Gnosticism as a Means of Legitimating Quasi-militant Democracy in Crisis-driven Poland
}

\section{Joanna Rak ${ }^{1}$ [D}

\begin{abstract}
Embedded in the theory of political gnosticism and drawing upon a qualitative content analysis of 246 pieces of news released by state media, this article examines a means of legitimating anti-democratic measures deployed during the first wave of the Covid-19 pandemic in Poland. The research aims to identify and explain the nature and origins of justification frames for quasi-militant democracy. The main argument is that journalists of the most popular state television, TVP Info, used political gnosticism to legitimate quasi-militant democracy. They exploited fears of losing one's life and health to convince citizens that the limitations of civil liberties are germane to survival and development. The research shows that the occurrence of all essential components of political gnosticism, used to justify anti-democratic actions in state media, is one of the indicators of anti-democratic changes in the political structure. It also provides insight regarding the theory of democratic erosion at a level of freedom of the press by offering evidence confirming the counter-democratic nature of quasi-militant democratic consolidation.
\end{abstract}

\section{Keywords}

Partisan journalism, Political gnosticism, Militant democracy, Legitimacy, Coronavirus Crisis, Poland

1 Corresponding Author: Joanna Rak (Assoc. Prof. Dr.), Adam Mickiewicz University, Faculty of Political Science and Journalism, Department of Political Culture, Poznań, Poland. E-mail: joanna.rak@amu.edu.pl ORCID: 0000-0002-0505-3684

To cite this article: Rak, J. (2021). Partisan Journalists on Duty: Political Gnosticism as a Means of Legitimating Quasimilitant Democracy in Crisis-driven Poland. SIYASAL: Journal of Political Sciences, 30(2), 207-224.

http://doi.org/10.26650/siyasal.2021.30.979419 


\section{Introduction}

In 2015, the Law and Justice (Prawo i Sprawiedliwość, hereafter 'PiS') candidate Andrzej Duda won the Polish presidential election in the second round. Then, as a result of parliamentary elections, for the first time in democratic Poland's history, the winning political party, in this case PiS, achieved a majority in the Sejm and formed a government as a coalition with United Poland (Solidarna Polska) and Agreement (Porozumienie) (Markowski, 2018). These electoral successes prompted a series of far-reaching political and legal changes within the Polish political regime, including dismantling institutional safeguards on the government by hamstringing the Constitutional Tribunal, and then transforming it into an active supporter of the government. Additionally, the courts' judges were subordinated to the government and several restrictions on individual and political rights, the right to assembly, privacy, and the freedom of the press were put into effect. The 2019 parliamentary election resulted in the continuation of the incumbent PiS party-coalition rule and a decline in the quality of democracy (Markowski, 2020). In 2020, using the Covid-19 crisis as a pretext and treating the pandemic as a justification for further anti-democratic activities (Alsarghali, 2020), the government imposed limitations on freedom of assembly, religious expression, and additional movement restrictions. Although the Polish Commissioner for Human Rights, Adam Bodnar found them unconstitutional and illegally implemented, they remained in effect and were enforced. Meanwhile, the limitations of active and passive voting rights, referendum organization, registration and functioning of political parties, naturalization, freedom of the press, legislation on anti-extremism, and restrictions on the independence of the judiciary were the militant democracy measures still in force (Malkopoulou, 2019, 2).

This article argues that the use of anti-democratic measures not to protect but undermine the sovereignty of the Polish political nation was the indicator of quasi-militant democracy. This anti-democratic structure required social legitimacy that must have been generated by the government and its partisan institutions to maintain the created political structure and limit room for dissent against the departure from liberal democracy.

Accordingly, the research focuses on the means of generating social legitimacy by the government's most influential partisan institution. It aims to identify and explain the nature and origins of justification frames for quasi-militant democracy. Those frames are the elements of political gnosticism in TVP Info concerning the Covid-19-driven anti-democratic measures used to justify and account for the drift towards quasi-militant democracy and its consolidation. Militant democracy is a political and legal structure whose aim is to use popularly supported democratic institutions to preserve democracy against those who strive to overturn it from within or those who openly seek to destroy it from the outside (Pfersmann, 2004, 47; Loewenstein, 1937). Thus, it safeguards the sovereignty of a political nation. Nevertheless, under the guise of protecting democracy against its presumed enemies, the limitations of rights and freedoms may allow the ruling class to arbitrarily exclude political competitors from the democratic game, ipso facto restricting the democratic nature of the regime. Since there is no principled way of determining what constitutes an enemy of democracy, the enemy cannot be established by democratic means. Instead, the definition of enemies becomes a sovereign exercise of authoritarian power. Militant democracy may be a democratic and constitutional cloak 
for authoritarian politics (Invernizzi Accetti \& Zuckerman, 2017). This article argues that when a political and legal structure restricts civil liberties not to preserve but to weaken or overturn liberal democracy and undermine the sovereignty of a political nation, a quasi-militant democracy emerges. Thereby, quasi-militant democracy is the opposite of militant democracy with respect to the objectives of anti-democratic measure deployment.

Furthermore, the article argues that the pandemic-driven drift towards quasi-militant democracy and its consolidation were legitimated throughout political gnosticism. The study revolves around a theoretical assumption that the means of legitimating political and legal structures closely adheres to the types of the same structures (Shorten, 2007, 172). It falls into the body of research on political religion as a source of a political regimes' legitimacy. Scholars started applying the term 'political religion' to address these means in the twentieth century, during the rise of two prominent ideologies that came to power, i.e., fascism and communism, and their use to legitimate autocracies (Aron, 2003, 183). They pointed to the sacralization of politics understood as the reoccurrence of the religious dimension in politics. Sacralization shifts modern politics from a more liberal paradigm, which reduces politics to an administration of rules of the free capitalist market, to a metaphysical approach wherein politics aim to come up with final solutions to deal with human fate, the society, and humanity (Shaqiri, 2019, 111).

On the one hand, political religion, called modern political gnosticism, serves to affirm that democratic erosion and nondemocratic regimes are right and morally correct (Payne, $2005,166)$. This type of discursive legitimation provides semantic structures that are indicative of anti-democratic tendencies within political regimes. They are necessary, but not sufficient components of nondemocratic systems. On the other hand, political gnosticism may be used to legitimate liberal democracy when it serves to maintain democratic fundamentalism in the state structure (Loewenstein, 1937, 423).

Modern political gnosticism draws upon a classic meaning of ancient gnosis ('knowledge'), its secularization through politicization, and criticism of modernism (Voegelin, 1987, 120). In a narrow sense, political gnosticism is a syncretic religious movement active mainly in the Eastern Mediterranean sphere of late antiquity. The movement made elitists claims of possessing 'knowledge of divine secret' and considered the spiritual core of the human being as taking part in the divine substance. Under certain conditions, this spiritual core can be redeemed by recognizing its true, transmundane character (Riegel, 2007, 62). In a broad sense, political gnosticism is a set of beliefs determining the interpretation of social reality. The creator, distributor, and redistributor of the beliefs considers them 'knowledge or knowing' (Rak, 2017). In this study, political gnosticism is defined as a political cognitive structure whose essential features are the following: splitting people into self and others, messianic visions of thoroughly remodeling society into a utopian dream state, political obscurantism as a mode of dealing with dangerous knowledge and creation of a total enemy, all these features coupled with various strategies of surviving on the historic battlefield. Political gnosticism used to justify and account for anti-democratic actions of the government is a type of political thinking characteristic of nondemocratic regimes.

These observations and theories have motivated the following research questions: How did partisan media subservient to the ruling party and government justify and account 
for the illegal implementation of Covid-19 pandemic-related anti-democratic measures? How did they convince Poles to acquiesce to the government? These questions lie at the heart of any attempt to legitimate quasi-militant democracy, i.e., affirming that this political and legal structure is justified, and that is in turn the main subject of this study.

The remainder of the article is organized into three major sections. The first one presents research methods, techniques, and tools. It also delves into the criteria for source selection, a corpus of materials, data gathering, coding, and analysis procedures. The following section discusses research results concerning the characteristics and intensity of political gnosticism in the news broadcasted by state television. The discussion begins with the introduction, drawing general conclusions about the dynamics and configuration of the elements of political gnosticism. Then, it goes into details of individual essential features of the justification frames. The last section makes theoretical sense of the use of political gnosticism to justify and explain Polish drift towards and the consolidation of a quasi-militant democracy.

\section{Materials and Methodological Assumptions for the Research}

The study tests the theory-grounded hypothesis that TVP Info used political gnosticism with regard to the Covid-19-driven implementation of anti-democratic measures to justify and explain the drift towards and the consolidation of quasi-militant democracy. TVP Info is a Polish free-to-air television news channel controlled by the state broadcaster, TVP. After the parliamentary election in 2015, PiS passed a media law giving the government direct control over public broadcasting and thus transformed public media into a progovernment propaganda outlet. According to the Institute for Media Monitoring, TVP Info was the most opinion-forming state media in January-March 2020 (IMM, 2020). At the same time, it was the most influential partisan institution in Poland.

To verify the hypothesis, the research applies the source analysis method that draws upon the qualitative content analysis of 246 pieces of news concerning anti-democratic measures. The corpus of news comprises all news released from the detection of Covid-19 for patient zero in Europe (24 January 2020) to 20 May 2020, when some states, including Poland, started lifting restrictions related to the Covid-19 pandemic. Thereby, the study covers the first wave of the pandemic in Poland; the time when the first Covid-19-related restrictions were introduced. As soon as possible, the government must have made an effort to establish the desired patterns of social behavior and gain support for its political decisions to maintain regime stability. Television news programs were a means of primary distribution of semantic structures used by the government to provide information regarding the pandemic threat and convince society to comply with the precautionary measures. Moreover, presidential elections were scheduled for May 2020. During elections, populist politicians are more prone to promote anti-democratic solutions and engage with polarizing discourses against total enemies (Boukala, 2014). It was also a time of increased efforts to generate support for the ruling party's candidate and delegitimize his opponents. A noteworthy point is that legitimacy for any political structure is not inevitable from the outset. Instead, it develops over time, and the selected period allows a researcher to investigate the nature and origins of justification frames for the Covid-19-driven drift towards and the consolidation of a quasi-militant democracy (Gerschewski, 2013, 14). 
The iterative process of document analysis includes skimming, thorough examination and interpretation. It combines components of content analysis and thematic analysis. The first step of content analysis involves identification of passages of texts that contain direct references to restrictions of freedom of movement, assembly, and religious worship. The second step entails the organization of information into categories related to the research questions and embedded in the theoretical framework: $\left(\mathrm{QI}_{1}\right)$ dividing people into self and others, $\left(\mathrm{QI}_{2}\right)$ change of present-day reality into a utopian dream state, $(\mathrm{QI})$ ) political obscurantism as a mode of dealing with dangerous knowledge, $\left(\mathrm{QI}_{4}\right)$ creation of a total enemy, and $\left(\mathrm{QI}_{5}\right)$ strategies of survival on the historic battlefield. Each feature takes on values that differ in intensity of political gnosticism (Rak, 2017). These qualitative indicators reflect values specific for hard, moderate, and soft political gnosticism (see Table 1). Thematic analysis enables the researcher to pinpoint themes pertinent to specific elements of political gnosticism and assign them appropriate values. Re-reading and reviewing selected data involves thematic analysis that consists of coding and category construction based on the data's characteristics (Bowen 2009). The coding of the document content is founded on five groups of search terms: (1) for dividing people: self, others, we, they, opponents, opposition, protesters, participants of public gatherings, violators of social norms and law, (2) for change of present-day reality into a utopian dream state: future, change, aspiration, development, advancement, growth, increase, direction, promise, (3) for political obscurantism as a mode of dealing with dangerous knowledge: news, information, knowledge, (4) creation of a total enemy: threat, danger, risk, jeopardy, hazard, and (5) for strategies of survival on the historic battlefield: survival, protection, precautions, norms, sanitary measures, regulations, law, solidarity, community, unity.

Table 1

The Set of Qualitative Indicators of Political Gnosticism

\begin{tabular}{|c|c|c|}
\hline $\mathrm{QI}_{\mathrm{n}}$ & $\begin{array}{l}\text { The qualitative indicators of } \\
\text { political gnosticism }\end{array}$ & $\begin{array}{l}\text { The values of the qualitative indicators } \\
\text { (1) low intensity (soft political gnosticism) } \\
\text { (2) moderate intensity (moderate political gnosticism) } \\
\text { (3) high intensity (hard political gnosticism) }\end{array}$ \\
\hline $\mathrm{QI}_{1}$ & $\begin{array}{c}\text { Dividing people into self and } \\
\text { others }\end{array}$ & $\begin{array}{l}\text { (1) defensive relativization of 'we-insiders' and offensive } \\
\text { relativization of 'they-outsiders' } \\
\text { (2) melioration of 'we-insiders' and pejorativization of 'they- } \\
\text { outsiders' } \\
\text { (3) anthropolatrization of 'we-insiders' and vilification of 'they- } \\
\text { outsiders' }\end{array}$ \\
\hline $\mathrm{QI}_{2}$ & $\begin{array}{c}\text { Change of present-day reality into } \\
\text { a utopian dream state }\end{array}$ & $\begin{array}{l}\text { (1) nonviolent means or unspecified methods } \\
\text { (2) threat } \\
\text { (3) physical violence }\end{array}$ \\
\hline $\mathrm{QI}_{3}$ & $\begin{array}{l}\text { Political obscurantism as a } \\
\text { mode of dealing with dangerous } \\
\text { knowledge }\end{array}$ & $\begin{array}{l}\text { (1) tabooing dangerous knowledge } \\
\text { (2) faking dangerous knowledge } \\
\text { (3) exterminating dangerous knowledge }\end{array}$ \\
\hline $\mathrm{QI}_{4}$ & Creation of a total enemy & $\begin{array}{l}\text { (1) a threat to the stable functioning of the ingroup and the } \\
\text { internal world } \\
\text { (2) a threat to the material security of the ingroup and the internal } \\
\text { world } \\
\text { (3) a threat to the ingroup's lives and health and internal world } \\
\text { existence }\end{array}$ \\
\hline $\mathrm{QI}_{5}$ & $\begin{array}{l}\text { Strategies of survival on the } \\
\text { historic battlefield }\end{array}$ & $\begin{array}{l}\text { (1) escapism } \\
\text { (2) isolation } \\
\text { (3) annihilation }\end{array}$ \\
\hline
\end{tabular}

Source: Author's own study. 
The segregation of people consists in differentiating between 'we-insiders' and 'they-outsiders' $\left(\mathrm{QI}_{1}\right)$. The first indicator takes on high value (3) when a communicator considers the ingroup as divine while demonizing the outgroup. Anthropolatrization and vilification entail an extremely positive and negative valuation, respectively. Moderate intensity (2) comes in the form of assigning positive traits to the ingroup and negative ones to the outgroup. Low intensity (1) manifests itself as portraying the ingroup as better than others or not as bad as others while the outgroup as worse or not as good as others.

While the first indicator concerns the semantic creation of present-day reality, the second one $\left(\mathrm{QI}_{2}\right)$ depicts what political reality (of a utopian nature) should be created and how to achieve that lofty goal in the future. The intensity of political gnosticism depends on a change variant that provides sense for the activities of the communicator. A homogeneous criterion for the variant distinction is a means of changing unacceptable reality into a utopian state. A high intensity (3) includes the use of active physical violence. The moderate form (2) rests on the use of threat, or passive physical violence. A low intensity (1) emerges through nonviolent means or unspecified methods.

The third indicator relates to political obscurantism as a mode of dealing with dangerous knowledge $\left(\mathrm{QI}_{3}\right)$. A communicator purposefully withholds information from dissemination to maintain an existing order or establish a new one. Intrusive information is hence considered detrimental to the transformation of present-day reality into a desired state, as it supports the outgroup, the total enemy, and threatens the ingroup and the integrity of the supposedly 'good' world. The strategy of attacking non-gnostic knowledge determines the intensity of political gnosticism. A high intensity (3) emerges if a communicator displays overt hostility towards dangerous knowledge, which is to be annihilated. A moderate intensity (2) entails presenting non-gnostic knowledge as fake, misleading news. A low intensity (1) is achieved by tabooing non-gnostic knowledge, or rendering certain information unmentionable.

The total enemy's sole objective is allegedly to destroy and deploy violence. Its hostility stems from its inherent essence, and with whom coexistence is impossible because it precludes peace and prosperity. The construction of a total enemy $\left(\mathrm{QI}_{4}\right)$ that meets these criteria is the fourth indicator of political gnosticism. The ingroup strives to design, punish, and exterminate a total enemy just because he/she is the source of disturbing insecurity, precludes the transformation of present-day reality, and threatens the ingroup. Total enemies differ in how they threaten the ingroup and the internal world. A high intensity of political gnosticism (3) is when the total enemy becomes a menace to the ingroup's lives, health, and the existence of the internal world. A moderate intensity (2) appears if the total enemy endangers the material security of 'we-insiders' and 'our world.' Material security is violated when people lose material resources, or when public property is damaged. A low intensity (1) emerges when the total enemy jeopardizes the stable functioning of the internal world and those who belong to it.

Finally, political gnosticism may also be typified by strategies of survival on the historic battlefield $\left(\mathrm{QI}_{5}\right)$. A desire for self-perpetuation results in strategies pertaining to survival on historic battlefields understood as spaces where good and evil clash. Hard political gnosticism takes the form of annihilation (3), and rests on claiming that nongnostic resources, either material or non-material, are to be annihilated and condemned 
as inconsistent with the native world. Non-gnostic resources are beings, processes, and phenomena that do not belong to the ingroup and are incompatible with its goals. Isolation is a characteristic of a moderate intensity (2). It draws on the separation of the native world from non-gnostic resources. A low intensity (1) takes the form of escapism, or avoidance of being in any relationship with non-gnostic resources. Hard political gnosticism is more actively on the offensive while its moderate and soft forms are defensive.

Data analysis is entrenched by a constant comparative method which rests on an inductive approach taken to identify the political gnosticism-related theoretical properties in the data. A back-and-forth interplay with the data enables the researcher to investigate the codes and concepts. Data is juxtaposed whiles codes are used to structure ideas and identify clustering concepts (Bowen, 2009).

The following parts of the article discuss the dynamics, occurrence, and intensity of political gnosticism in the news at five definitional levels. They introduce how partisan journalists legitimated the illegally implemented Covid-19 pandemic-derived antidemocratic measures. They delve analytically into journalist practices used to convince Poles to become obedient to the government.

\section{Research results and discussion}

No later than March, partisan journalists began using political gnosticism to convince the Polish populace to accept and comply with anti-democratic restrictions. It was then that the first case of infection with the virus was detected in Poland and the first wave of the pandemic officially began. The intensity and number of political gnosticism elements were changing. These elements occurred 322 times in March (32\% of all the elements), 44 times in April (4\%), and 648 times in May (64\%) (Table 2). In March, political gnosticism emerged as a reaction to government decisions to impose limitations of civil liberties. TVP Info unreservedly supported the government and justified anti-democratic measures. The state broadcaster's duty was not to prepare society for potential restrictions prior to their imposition but to convince Poles that the already implemented changes were suitable for the situation. The intensity and number of political gnosticism elements were relatively high because of apprehension in regard to expected social contestation over anti-democratic measures. Civil movements opposing democratic erosion, especially the Committee for the Defense of Democracy (CDD) and the Citizens of Poland, which had been established before the pandemic, monitored the activities of the political regime, and planned to launch protests against over-restrictive regulations. Therefore, the government might have expected that protest activity would continue during the pandemic. 
Table 2

The Elements of Political Gnosticism in TVP Info News Legitimating Anti-Democratic Measures

\begin{tabular}{|c|c|c|c|c|}
\hline \multirow[t]{2}{*}{$\mathrm{QI}_{\mathrm{n}}$} & \multicolumn{4}{|c|}{ The intensity of political gnosticism: (1) low, (2) moderate, and (3) high. } \\
\hline & March 2020 & April 2020 & May 2020 & March-May 2020 \\
\hline $\mathrm{QI}_{1}$ & $\begin{array}{c}\text { (1) } 0 \\
\text { (2) } 8 \\
\text { (3) } 62 \\
\text { Total: } 70\end{array}$ & $\begin{array}{c}\text { (1) } 0 \\
\text { (2) } 1 \\
\text { (3) } 7 \\
\text { Total: } 8 \\
\end{array}$ & $\begin{array}{c}\text { (1) } 0 \\
\text { (2) } 8 \\
\text { (3) } 87 \\
\text { Total: } 95 \\
\end{array}$ & $\begin{array}{c}\text { (1) } 0 \\
\text { (2) } 17 \\
\text { (3) } 156 \\
\text { Total: } 173(17 \%) \\
\end{array}$ \\
\hline $\mathrm{QI}_{2}$ & $\begin{array}{c}\text { (1) } 21 \\
\text { (2) } 42 \\
\text { (3) } 28 \\
\text { Total: } 91 \\
\end{array}$ & $\begin{array}{c}\text { (1) } 4 \\
\text { (2) } 2 \\
\text { (3) } 0 \\
\text { Total: } 6\end{array}$ & $\begin{array}{c}\text { (1) } 61 \\
\text { (2) } 78 \\
\text { (3) } 65 \\
\text { Total: } 204 \\
\end{array}$ & $\begin{array}{c}\text { (1) } 86 \\
\text { (2) } 122 \\
\text { (3) } 93 \\
\text { Total: } 301(30 \%)\end{array}$ \\
\hline $\mathrm{QI}_{3}$ & $\begin{array}{c}\text { (1) } 21 \\
\text { (2) } 15 \\
\text { (3) } 19 \\
\text { Total: } 55\end{array}$ & $\begin{array}{c}\text { (1) } 3 \\
\text { (2) } 4 \\
\text { (3) } 5 \\
\text { Total: } 12 \\
\end{array}$ & $\begin{array}{c}\text { (1) } 39 \\
\text { (2) } 23 \\
\text { (3) } 32 \\
\text { Total: } 94\end{array}$ & $\begin{array}{c}\text { (1) } 63 \\
\text { (2) } 42 \\
\text { (3) } 56 \\
\text { Total: } 161(16 \%)\end{array}$ \\
\hline $\mathrm{QI}_{4}$ & $\begin{array}{c}\text { (1) } 29 \\
\text { (2) } 12 \\
\text { (3) } 33 \\
\text { Total: } 74\end{array}$ & $\begin{array}{c}\text { (1) } 4 \\
\text { (2) } 3 \\
\text { (3) } 3 \\
\text { Total: } 10 \\
\end{array}$ & $\begin{array}{c}\text { (1) } 48 \\
\text { (2) } 45 \\
\text { (3) } 71 \\
\text { Total: } 164 \\
\end{array}$ & $\begin{array}{c}\text { (1) } 81 \\
\text { (2) } 60 \\
\text { (3) } 107 \\
\text { Total: } 248(24 \%) \\
\end{array}$ \\
\hline $\mathrm{QI}_{5}$ & $\begin{array}{c}\text { (1) } 0 \\
\text { (2) } 0 \\
\text { (3) } 32 \\
\text { Total: } 32 \\
\end{array}$ & $\begin{array}{c}\text { (1) } 0 \\
\text { (2) } 0 \\
\text { (3) } 8 \\
\text { Total: } 8\end{array}$ & $\begin{array}{c}\text { (1) } 0 \\
\text { (2) } 0 \\
\text { (3) } 91 \\
\text { Total: } 91\end{array}$ & $\begin{array}{c}\text { (1) } 0 \\
\text { (2) } 0 \\
\text { (3) } 131 \\
\text { Total: } 131(13 \%)\end{array}$ \\
\hline Total & $322(32 \%)$ & $44(4 \%)$ & $648(64 \%)$ & Total: $1014(100 \%)$ \\
\hline
\end{tabular}

Source: Author's own study.

A substantial decrease in the number of political gnosticism elements in April was the result of almost complete social compliance with restrictions and acquiescence to government instructions. However, in May, the political gnosticism rate considerably increased and achieved the highest level during the pandemic. The rate increased as more anti-government public gatherings took place. Assemblies steadily increased in numbers and intensity. They were initially prompted by growing unrest regarding the progressive weakening of democratic governance, dissatisfaction with Covid-19-related precautions, and the socio-economic consequences of the pandemic, mainly in the form of unemployment. The state broadcaster took the government's side again. TVP Info made an active and explicit effort to justify and account for the imposition of Covid-19related limitations while criticizing those who opposed the government.

\section{Dividing People into Self and Others}

TVP Info clearly determined differences between 'we-the good' and 'they-the bad.' About $17 \%$ of all manifestations of political gnosticism featured this strategy. Hard gnosticism was dominant, the moderate variant rare, and the soft one did not occur. Accordingly, TVP Info mostly used extreme valuation to define the ingroup and the outgroup. This is demonstrated by the occurrence of firm and uncompromising distinctions. Anthropolatrization of 'we-insiders' and vilification of 'they-outsiders' took the form of two types of division.

A criterion for the first division was an imagined attitude towards adherence to the law. While the ingroup integrated those who respected the limitations of civil liberties imposed by the government, the outgroup consisted of those who did not and supposedly put the lives and health of all people in jeopardy, e.g., opposition members who supported anti-government social initiatives (TVP Info 2020d, 2020q, 2020t). Other news 
exacerbated this division by incorporating into the outgroup distributors of fake news and participants of public gatherings considered illegal, including the representatives of the opposition parties and the presidential candidates who were not supported by PiS (i.e., Duda's counter-candidates) (TVP Info, 2020j, 20201). TVP Info condemned the outgroup actions, such as public gathering held by Duda's counter-candidates during their election campaigns, as fatally dangerous and immoral (TVP Info, 20201). They were contrary to the law and the government's anthropolatrized aspiration to protect human lives and health.

The other division criterion conjured up attitude towards the crisis itself. The broadcaster utilized police statements that separated the anthropolatrized 'our citizens' from the vilified 'fraudsters.' The latter group was involved in money scams revolving around the fight against the coronavirus, e.g., ostensible 'miracle' medicines, vaccines for the virus, or fake tests to detect infection. Their alleged behavior put lives at risk. They breached the law and violated crucial social norms. The outgroup was juxtaposed with the police that identified and apprehended the perpetrators who did not belong to the category of 'our citizens' despite their indeterminate provenance (TVP Info, 2020f). Such framing of the situation allowed journalists to exclude from the ingroup those people who took advantage of the pandemic for their own benefit. It also legitimated police actions aimed at protecting Poles and maintaining public order on behalf of the government.

Considerably less frequent was moderate political gnosticism. According to TVP Info, the implementation of anti-democratic measures contributed to the general progress of the law-abiding ingroup. Those people supposedly started using new instant messaging clients, participated in video chats, commented on posts on social media, and generally gained from remote learning (TVP Info, 2020e). In turn, the outgroup failed to embrace these opportunities. Journalists attached positive and negative values to the representatives of the two groups on the basis of presumed utilization of new technologies. Interference in the private sphere consisted in determining a catalog of desirable behaviors that allowed closer affiliation with the ingroup. In effect, the broadcaster presented a series of actions deemed acceptable and commendable.

The broadcaster avoided using defensive relativization of 'we-insiders' and offensive relativization of 'they-outsiders.' The groups were considered incomparable and deprived of any common features, which contributed to a strong polarization of Poles. The lack of soft political gnosticism against the background of its harder forms revealed a reluctance to soften rigid divisions. The divisions provided instructions for the ingroup's desirable behavior in public and private spheres. The instructions stated that good citizens should have stayed home, focused on self-development or entertainment, avoided participating in protests and engaging in anti-government initiatives. They shaped the perception of properly fulfilled political roles.

\section{Change of Present-day Reality into a Utopian State}

This future-oriented feature was the most significant component of political gnosticism due to its largest share in the news (30\%). The introduction of anti-democratic measures was shown as a necessary stage in the development of the political and legal structure. Although TVP Info offered a wide range of ideas to change the political reality, threat- 
based moderate political gnosticism prevailed. As the broadcaster informed the public, the government was ready and willing to resort to active physical violence to meet its goals. Slightly less frequent were the soft and hard variants. The former involved nonviolent and unspecified methods, which might have been replaced with force. The latter included active physical violence. Importantly, hard political gnosticism did not occur in April, when social obedience to the Covid-19-related law was at its highest level. At that time, threats were sufficiently preventive, and active physical violence was considered unnecessary. The highest rates in May stemmed from the need to show the strategies of dealing with participants of anti-government public gatherings, including those held by Duda's counter-candidates.

The public broadcaster, fulfilling the goals of the repressive state, disseminated the National Police Chief's guidelines. The police, an officially apolitical institution, actively supported the government during the pandemic and their actions fit into the model of partisan policing. The police announced that 20,000 officers, supported by paramilitary officers, soldiers, and city guards, would enforce order in Polish cities (TVP Info, 2020f). This would generate a much larger number of patrols on the streets to control and check how the provisions of government regulations were observed. The police would repress those who disregarded the limitations established by the law, use prevention, and educate offenders (TVP Info, 2020i). Police officers called on people to report all violations. TVP Info promoted attitudes of absolute obedience and compliance with restrictions resulting from quasi-militant democracy consolidation. In a utopian state depicted by journalists, the rules determined by the government were absolutely respected. The way to achieve this goal was typical of hard political gnosticism since it involved force against Poles whose behavior infringed state regulations.

TVP Info reported that the President, Prime Minister, and Minister of Health presented a vision of a pandemic-free Poland. The way to protect Polish citizens' lives and health was to limit civil liberties such as freedom of assembly (TVP Info, 2020k, 2020m, 2020n). Anti-democratic measures were understood as an efficient means of fighting the pandemic. The Minister of Health appealed to Polish citizens to take responsibility for 'loved ones, neighbors, and everyone we meet' (TVP Info, 2020s). In a time of crisis, responsibility rested on upholding the law and making sure others do so as well, which might have been considered as informing against offenders (TVP Info, 2020i). The threats of violence and punishment for failure to comply with the restrictions were indicative of moderate political gnosticism.

Soft political gnosticism also served to define plans for the future. The Prime Minister referred to the possible influence of the after-pandemic global crisis on Poland. He compared the economic situation in Poland with Great Britain to show that the former was in a more advantageous position thanks to its government. Therefore, anti-democratic measures imposed by the government were adequately selected and efficient. As TVP Info broadcasted, the government aimed at a significantly lower economic slump in Poland and sought to curb the possible surge in unemployment. The Prime Minister imprecisely outlined the means to achieve these goals: 'to do everything possible as part of our anticrisis shield' (TVP Info, 2020a). The lack of references to violent methods indicated the low intensity of political gnosticism. Simultaneously, however, the lack of developed 
ideas for achieving the assumed goals became apparent. The use of violent solutions could not be ruled out in the face of declarations to employ all possible means.

The original use of soft political gnosticism emerged in the President's objection to the regionalization of Poland. As the President stated, 'only a state as strong as Poland could efficiently fight the pandemic,' which was 'a lesson for the future' (TVP Info, 2020b). Andrzej Duda aimed to strengthen state power as 'an indiscrete entity' (TVP Info, 2020b). On the one hand, media tried to actively create the impression of looming success towards the end of the pandemic. On the other, they were promising future security and prosperity. The President did not assume the use of force as necessary in order to alter the existing reality, yet his vision of the future left little room for alternatives. Therefore, any threat to this idyllic future could be met with a violent push-back.

TVP Info supported the government's plans for the future. Journalists espoused the vision of Poland as a strong state free of widespread coronavirus infections and as doing significantly better economically than other European states. Poles were supposed to respect the rules and restrictions implemented by the government. Common repression, police prevention, education, civil obedience, denunciatory activities, preventing state regionalization, limitation of civil liberties, the imposition of 'anti-crisis shields,' and 'doing everything we [the government] can' (TVP Info, 2020b) were considered appropriate means to achieve the lofty goal of a perfect future state. An extensive catalog of measures, including active physical violence, testified to the government's unwavering pursuit of this path.

\section{Political Obscurantism as a Mode of Dealing with Dangerous Knowledge}

Sixteen percent of political gnosticism elements served the broadcaster to tackle dangerous knowledge. TVP Info solely distributed information that reinforced government policy. Journalists used strategies of tabooing, faking, and exterminating. The exact choice of strategy was dictated by the sense of danger that any inimical narrative posed to TVP Info's own discursive creation.

A form of hard political gnosticism was deployed against hostile communicators. The Prime Minister declared 'a war against the pandemic of fake news and misinformation' since this 'pandemic might have accelerated the development of the Covid-19 pandemic' (TVP Info, 2020m). The end result was that any narrative that was incompatible with the state's was rendered 'fake news' and hence banished from the public media sphere.

The announcements of the imposition of anti-democratic measures contained neither substantive justification for nor explanation of particular restrictions (TVP Info, 2020q). The Minister of Health criticized Great Britain for not limiting the freedom of assembly and thus contributing to the spread of the coronavirus. His assertion was that such limitations were absolutely critical and necessary (TVP Info, 2020h). Moreover, TVP Info described the state successes in combating the pandemic by quoting supporters praising anti-democratic measures (TVP Info, 2020n). These measures were treated as a non-alternative source of Poland's efficiency in the fight against the pandemic. TVP Info tabooed any counterarguments and thus applied soft political gnosticism.

TVP Info appealed to opposition groups to 'stop distributing harmful fake news' (TVP Info, 2020k). The use of moderate political gnosticism consisted in treating the information 
distributed by the opposition as false and hostile. According to the Minister of the Interior and Administration, restrictions stemmed from the epidemic threat rather than the will to restrict civil rights (TVP Info, 2020r). He used moderate political gnosticism by rejecting opinions incongruous with state narration. Any counterarguments were treated as fake news misleading society. No substantive discussion followed that supposition.

Moderate political gnosticism also occurred in news about protest policing. As TVP Info emphasized, participants of illegal gatherings were detained because they attacked and wounded police officers. In contrast to whatever the participants maintained and the independent media showed, the police were free from blame. Nevertheless, apart from this brief comment, the broadcaster ignored the other side's viewpoints on the current affairs (TVP Info, 2020o, 2020p). Journalists avoided delving into narrations inconsistent with their own interpretation of clashes between the police and protesters. These narrations were rejected as fake news produced to slander the police engaged in law enforcement.

As TVP Info indicated, verified information on coronavirus was available on official government profiles in social media and on websites with the domain gov.pl. This is evidence of an attempt to monopolize information distribution channels and, at the same time, exclude other sources, which is a form of soft political gnosticism. The broadcaster drew on the Prime Minister's appeal to Poles to be careful when searching for information because 'one false message can lead to many unpleasant events, to the tragedy of other people' (TVP Info, 2020m) and warned that, 'even a photograph may have dire consequences. An innocent photo that is misleading can lead to panic; such a snowball effect may be hard to stop' (TVP Info, 2020m). Therefore, other sources of information than those approved by the government put Polish citizens at risk.

Strategies for using this type of political gnosticism showed that journalists created a particular image of Poland and actively prevented its modification by alternate information channels. The emergence of hard political gnosticism revealed a sense of danger allegedly posed by other information centers. The defense-by-attack mechanism was applied. Furthermore, the broadcaster discredited political opponents to lower their credibility. In turn, keeping information silent was a symptom of a sense of relative control over the distribution of news and its impact on the audience.

\section{Creation of a Total Enemy}

The creation of a total enemy was the second most significant feature of political gnosticism ( $24 \%$ of all expressions). Hard gnosticism dominated since enemies were shown as a threat to human lives, health, and internal world existence. However, enemies also threatened the stable functioning of the ingroup, Poland, and, to a lower extent, Poles' material security.

Hard political gnosticism prevailed in information materials pertaining to antigovernment public gatherings. According to the broadcaster, their participants endangered themselves and Poles due to the very act of participating against the law (TVP Info, 2020o). They were considered criminals. Protesters used physical violence against the police, failed to keep social distance, and did not wear face masks (TVP Info, 20201). Activists were presented as the most dangerous total enemy. They constituted the largest group resisting the government. 
TVP Info also used hard political gnosticism to make Tomasz Grodzki, Marshal of the Senate of the Republic of Poland, a total enemy. The broadcaster claimed that Grodzki jeopardized the lives and health of senators and foreigners present at the Senate building by calling a meeting of the Senate. Although one of the people who were often at the Senate reported to the Marshal that he was feeling unwell and would undergo a coronavirus test, Grodzki did not change his decision (TVP Info, 2020g). By putting human lives and health at risk, the enemy threatened a community of mutually caring citizens.

According to state narration, the opposition popularized dangerous methods of bypassing the law. TVP Info quoted a member of the Civic Platform who recommended that the Church should have organized a second Christmas carol to provide people with the opportunity to receive Holy Communion and thus ease the consequences of restrictions on religious worship (TVP Info, 2020k). The editorial comment emphasized that this violation of restrictions would have put human lives and health in peril. Using hard political gnosticism, journalists exposed the supposedly hostile intentions of the opposition. A disregard for human life fueled ideas of bypassing state-imposed regulations, such as the ban on church gatherings.

Moderate political gnosticism occurred in news about illegal public gatherings. Their participants were enemies that damaged public property, including police cars (TVP Info, 2020c). These violations were deliberately aimed at the material security of Poles.

The ruling party used soft political gnosticism to present the CDD as a total enemy. The CDD is a civic organization that speaks against limitations on democracy, the rule of law, and civil liberties. The organization built a tent town called 'Freedom' next to the Sejm building. This makeshift space served as a haven for those who protested against the violations of democracy. In a statement for TVP Info, a member of the PiS contemptuously referred to the town as an 'encampment' and expressed his 'bewilderment' that activists 'occupied' the place despite the pandemic. He considered the haven as a threat due to 'sanitary,' 'moral,' and 'ethical reasons' (TVP Info, 20201) and underlined that 'particularistic-political demonstration' was immoral while other people were fighting for their lives. Another member of the PiS supported this view and indicated that the CDD acted at variance with those fighting for the common good. As journalists underlined, CDD activists opposed anti-democratic measures and breached restrictions. Thereby, the enemy threatened the stable functioning of the ingroup that complied with the new rules. Moreover, the parliamentary opposition also endangered the stable functioning of the state and Polish citizens by disseminating fake news that allegedly instigated anxiety and panic. This is a manifestation of soft political gnosticism since the enemy of the people is presented as a source of turmoil and confusion.

TVP Info legitimated the deployment of anti-democratic measures by introducing the following enemies: the opposition, Marshal of the Senate of the Republic of Poland hailing from the opposition, and civic organizations opposing democratic erosion. The way these edifices were presented was a sign of a lack of will to negotiate and cooperate. TVP Info did not create any external enemies, rather, all total enemies came from Poland, its own political structure. It generated a sense of fear and the need to be alert in the face of a ubiquitous internal threat. 


\section{Strategies of Survival on the Historic Battlefield}

The strategies of Poland's survival on the historic battlefield focused on the implementation of anti-democratic measures and strict adherence to them. This feature's share in political gnosticism manifestations was the lowest and amounted to $13 \%$. TVP Info only used an offensive strategy in the form of hard gnosticism. Defensive strategies of escapism and isolation did not occur. The configuration of the feature's values showed that the broadcaster maintained a confrontational stance throughout the pandemic.

As the broadcaster presented it, anti-democratic measures served to save human lives and health (TVP Info, 2020q). First, Poland combated the pandemic more efficiently than other European states just because of these measures. Second, the success in the struggle against the pandemic resulted from an almost complete lack of deviations from restrictions. The government armed the police with the right to interpret the law and decide whether citizens observed it. The police sought to maintain public order. Therefore, every violation was punished with repression and fines (TVP Info, 2020c). TVP Info provided examples of repression starting from adolescents (16-18 years old) who illegally met and, as a result, were fined or brought to justice thanks to exemplary civic responsibility in the guise of crime reporting. In turn, protesters who broke the law by gathering and injured police officers that secured the events were detained. Thereby, journalists stressed that anti-democratic measures had to be strictly observed, and even the smallest violations were severely punished. There was also a call for vigilance and fighting the enemy by means of cooperation with the police.

By drawing upon the Prime Minister's statements, the broadcaster pointed out that Poles demanded further restrictions on freedom of speech. Some 'citizens sent private messages on Facebook' to the Prime Minister to 'ask for punishing people for distributing fake news' (TVP Info, 2020k). Other citizens suggested that the opposition should have been punished for sharing information leading to anxiety and panic (TVP Info, 2020k). Showing support for anti-democratic measures, journalists legitimated the state narration. Accordingly, the general society appreciated the state media's contribution to combating the coronavirus and its undesired social consequences.

TVP Info treated the confrontational methods of fining and repressing as the only efficient means of suppressing those who did not respect the limitations put on civil liberties. The self-perpetuation of the political system and Poles depended on fearful obedience and absolute compliance.

\section{Conclusions}

As the analysis confirms, all the distinctive elements of political gnosticism occurred in their hard forms in the news that justified and accounted for the implementation of anti-democratic measures during the Covid-19 pandemic. The number and the intensity of political gnosticism elements depended on the intensity of expected and real social opposition to the government and anti-democratic measures. The greater the apprehension with regard to social resistance, the more numerous and harder political gnosticism elements were used to legitimate government narration and discard contentious subject matter. Since social contestation over democratic erosion had emerged due to prior 
anti-democratic measures before the pandemic, journalists expected its re-occurrence in March. They legitimated the measures immediately after their imposition by hard political gnosticism. The high intensity of political gnosticism served to discourage protests. In April, the indicators of political gnosticism dropped since the government had taken all measures to ensure that there was no actual state of emergency in order to hold presidential elections. TVP Info undertook to create a picture of a pandemic situation controlled by the government. It was so safe that elections could be organized without risking Poles' lives and health, and the government was prepared to meet organizational challenges.

In May, the number of political gnosticism elements grew along with an increase in real social opposition to the upcoming elections that re-emerged after the April lockdown. Although presidential elections were scheduled for May 2020, the voting planned for the first round did not take place. It was in the ruling party's interest to have these elections in May because as the economic situation worsened, the incumbent president Duda lost support, and the chances of his re-election decreased. At the same time, Bodnar was in favor of postponing the election date. He argued that holding elections on time would endanger Poles' health and lives. Moreover, while the ban on public assemblies was in force, only the ruling president could run an election campaign because the gatherings organized by him did not fall under the category of public assemblies within the meaning of the act amended during PiS's term of office. Finally, it was impossible to collect the required 100,000 signatures under the candidacy in a pandemic situation. The elections were passed against the Constitution and the rules of the Sejm. They could not be equal, universal, and secret. There was no regulation guaranteeing that all eligible voters would receive ballots and eliminating the possibility of illegal voting for others. The mechanisms for controlling the fairness of the elections were not provided. TVP Info displaced the counterarguments of the supporters of postponing the elections from the discourse and excluded them from the community of Poles.

This research contributes to Carlo Invernizzi Accetti's and Ian Zuckerman's (2017) theory of quasi-militant democracy by offering empirical evidence that sheds light on the counter-democratic nature of the deployment of Covid-19-related limitations. It confirms that the restrictions of civil freedoms, most of all the freedom of assembly and universal suffrage, provided the ruling with a means to exclude political competitors from the democratic game arbitrarily and thus limit the democratic nature of the regime instead of protecting democracy against its presumptive enemies. The process of defining total enemies was a sovereign exercise of authoritarian power due to a lack of a well-defined method of determining what constitutes an enemy of democracy. All those who actively opposed the consolidation of the quasi-militant democracy were classified as enemies. Accordingly, the study suggests that combining the current studies on militant democracy with the political gnosticism theory provides researchers with conceptual and theoretical tools to explore the political discourse used to generate social support for changes in political regimes.

This study has demonstrated how the semantic structures of political gnosticism worked as justification frames and legitimated anti-democratic measures. It has enriched our understanding of the nature and origins of generating social support for quasi-militant 
democracy during the Covid-19 pandemic in Poland through the partisan media. The analysis confirms that freedom of the press was limited since the plurality of views was insufficient and partisan journalists acted as loyal and active government supporters. The article also makes a theoretical contribution to the theory of nondemocratic regimes by formulating an explanatory model. It shows that the occurrence of all essential components of political gnosticism, used to justify anti-democratic actions, in state media is one of the indicators of anti-democratic changes in the political system and serves to legitimate them (Maier, 2007). It helps us understand the ways of thinking, which tend to solidify a very particular way of dealing with opponents (e.g., if we treat someone as an enemy, we do not think about a scenario where we cooperate with them). By recognizing the dominant ways of political thinking, analysts can predict the pool of scenarios that appear during the following waves and after the Covid-19 pandemic. Accordingly, the study shows that state media kept responding to threats to the vital interests of the government by increasing the number of elements and the intensity of political gnosis and thereby legitimating further anti-democratic actions. There were no signs of balancing between liberal democracy and quasi-militant democracy or heading towards the former. The main goal was to generate the highest possible social support for the consolidation of the created political and legal structure.

Peer-review: Externally peer-reviewed.

Conflict of Interest: The authors have no conflict of interest to declare.

Grant Support: This research paper is a result of the research project Contentious Politics and Neo-Militant Democracy. It was financially supported by the National Science Centre, Poland [grant number 2018/31/B/HS5/01410].

\section{References}

\section{Subject literature}

Alsarghali, S. (2020). The 'State of Emergency' or the 'State of Exception'? Bahrain and COVID-19. Global Discourse. An Interdisciplinary Journal of Current Affairs, 10(4), 445-454. https://doi.org/10.1332/20437 $8920 \times 16015781496746$

Aron, R. (2003). The Dawn of Universal History: Selected Essays from a Witness to the Twentieth Century. New York, NY: Basic Books.

Boukala, S. (2014). Waiting for Democracy: Political Crisis and the Discursive (Re)invention of the 'National Enemy' in Times of 'Grecovery'. Discourse \& Society, 25(4), 483-499. https://doi. org/10.1177/0957926514536961

Bowen, G. A. (2009). Document Analysis as a Qualitative Research Method. Qualitative Research Journal, 9(2), 27-40. http://dx.doi.org/10.3316/QRJ0902027

Gerschewski, J. (2013). The Three Pillars of Stability: Legitimation, Repression, and Co-optation in Autocratic Regimes. Democratization, 20(1), 13-38. http://dx.doi.org/10.1080/13510347.2013.738860

IMM. (2020). The Most Opinion-forming Media in 2020. https://www.imm.com.pl/tag/najbardziejopiniotworcze-media/ [Accessed: 5 August 2021]

Invernizzi Accetti, C., \& Zuckerman I. (2017). What's Wrong with Militant Democracy? Political Studies, 65(1S), 182-199. https://doi.org/10.1177/0032321715614849

Loewenstein, K. (1937). Militant Democracy and Fundamental Rights, I. The American Political Science Review, 31(3), 417-432. https://doi.org/10.2307/1948164

Maier, H. (2007). Political Religion: A Concept and Its Limitations. Totalitarian Movements and Political Religions, 8(1), 5-16. https://doi.org/10.1080/14690760601121614

Malkopoulou, A. (2019). Militant Democracy and Its Critics.” In A. Malkopoulou \& A. S. Kirshner (Eds.), Militant Democracy and Its Critics: Populism, Parties, Extremism (pp. 1-12). Edinburgh, UK: Edinburgh University Press.

Markowski, R. (2018). Backsliding into Authoritarian Clientelism: The Case of Poland. In P. Guasti \& Z. 
Mansfeldová (Eds.), Democracy Under Stress: Changing Perspectives on Democracy, Governance and Their Measurement (pp. 95-118). Prague: Institute of Sociology of the Czech Academy of Sciences.

Markowski, R. (2020). Plurality Support for Democratic Decay: The 2019 Polish Parliamentary Election. West European Politics, 43(7), 1513-1525. https://doi.org/10.1080/01402382.2020.1720171

Payne, S. G. (2005). On the Heuristic Value of the Concept of Political Religion and Its Application. Totalitarian Movements and Political Religions, 6(2), 163-174.

Pfersmann, O. (2004). "Shaping Militant Democracy: Legal Limits to Democratic Stability.” In A. Sajó (Ed.), Militant Democracy (pp. 47-68). Utrecht: Eleven International Publishing.

Rak, J. (2017). Justifying the Use of Violence: A Gnostic Deconstruction of a Political Universe. In J. Diec (Ed.) Deconstruction of Natural Order: The Legacy of the Russian Revolution (pp. 97-119). Kraków: Księgarnia Akademicka [Academic Bookshop].

Riegel, K.-G. (2007). Marxism-Leninism as Political Religion.” In H. Maier \& M. Schäfer (Eds.) Totalitarianism and Political Religions. Volume II: Concepts for the Comparison of Dictatorships (pp. 61-112). London and New York: Routledge.

Shaqiri, M. (2019). The Elements of Political Religion in the Post-conflict Society of Kosovo. Journal for the Study of Religions and Ideologies, 18(52), 110-124.

Shorten, R. (2007). "The Status of Ideology in the Return of Political Religion Theory. Journal of Political Ideologies, 12(2), 163-187. https://doi.org/10.1080/13569310701285016

Voegelin, E. (1987). The New Science of Politics: An Introduction. Chicago and London: The University of Chicago Press.

\section{Sources:}

TVP Info. (2020a). The First News: W walce z epidemią Polska wykonała lepszą robotę niż zamożniejsze kraje UE [The First News: In the Fight Against the Epidemic, Poland Has Done a Better Job than the Richer EU Countries]. May 3. https://www.tvp.info/47856178/the-first-news-w-walce-z-epidemia-polska-wykonalalepsza-robote-niz-zamozniejsze-kraje-ue [Accessed: 5 August 2021]

TVP Info. (2020b). Andrzej Duda. https://www.tvp.info/47653470/andrzej-duda [Accessed: 5 August 2021]

TVP Info. (2020c). Dodatkowe ograniczenia w przemieszczaniu się. Poznaj szczegóły [Additional Movement Restrictions. Get the Details]. March 24. https://www.tvp.info/47254028/nowe-ograniczenia-wprzemieszczaniu-sie-poznaj-szczegoly-wieszwiecej [Accessed: 5 August 2021]

TVP Info. (2020d). Droga krzyżowa w czasach koronawirusa: Kościół zaprasza na transmisje online [Stations of the Cross in the Coronavirus Age: The Church Invites You to Broadcast Online]. March 27. https://www. tvp.info/47301898/koronawirus-zakaz-wychodzenia-z-domu-w-polsce-droga-krzyzowa-w-interneciekosciol-zaprasza-na-transmisje-online-wieszwiecej [Accessed: 5 August 2021]

TVP Info. (2020e). Izolacja wywołała rewolucję w komunikowaniu [Isolation Sparked a Revolution in Communication]. April 15. https://www.tvp.info/47574280/koronawirus-polska-wirtualne-zycie-toczy-siebez-dystansowania-spolecznego-wieszwiecej [Accessed: 5 August 2021]

TVP Info. (2020f). Koronawirus przepłoszył większość przestępców, ale nie oszustów [The Coronavirus Scared Away Most Criminals, But Not the Scammers]. April 1. https:/www.tvp.info/47373193/koronawirusprzeploszyl-wiekszosc-przestepcow-ale-nie-oszustow [Accessed: 5 August 2021]

TVP Info. (2020g). Marszałek Grodzki lekceważy zagrożenie [Marshal Grodzki Disregards the Threat]. March 12. https://wiadomosci.tvp.pl/47098120/marszalek-grodzki-lekcewazy-zagrozenie [Accessed: 5 August 2021]

TVP Info. (2020h). Minister Szumowski komentuje zachowanie brytyjskiego rządu ws. epidemii [Minister Szumowski Comments on the Behavior of the British Government Regarding the Epidemic]. March 16. https://www.tvp.info/47142704/szumowski-o-rzadzie-wielkiej-brytanii-i-ich-dzialaniach-wz-zkoronawirusem-wieszwiecej [Accessed: 5 August 2021]

TVP Info. (2020i). Nastolatki złamały zakaz zgromadzeń w związku z koronawirusem. Słono zapłacą [Teenagers Have Broken the Assembly Ban over the Coronavirus. They Will Pay Dearly]. March 27. https://www.tvp. info/47301137/koronawirus-malbork-zakaz-wychodzenia-z-domu-nastolatki-zlamaly-zakaz-zgromadzenwieszwiecej [Accessed: 5 August 2021]

TVP Info. (2020j). Nielegalne zgromadzenie Obywateli RP przed Sejmem. Mandaty, wnioski do sądu [Illegal Assembly of Polish Citizens Before the Sejm. Fines, Court Applications]. May 7. https://www. tvp.info/47927445/protest-obywateli-rp-przed-sejmem-policja-nielegalne-spontaniczne-zgromadzenie-samandaty-i-wnioski-do-sadu-wieszwiecej [Accessed: 5 August 2021]

TVP Info. (2020k). Poseł KO mówi o zamkniętych sklepach i wojsku na ulicach. 'Takie fake newsy powinny być karalne' [KO MP Talks About Closed Shops and the Army in the Streets. 'Such Fake News Should Be Punishable']. March 13. https://www.tvp.info/47112848/koronawirus-politycy-opozycji-powtarzajanieprawdziwe-informacje-wieszwiecej [Accessed: 5 August 2021]

TVP Info. (20201). Poseł KO o koczowisku KOD przed Sejmem: Lepiej jakby zostali w domach [KO Deputy About the Camp KOD Before the Sejm: Better if They Stayed at Home]. March 31. https://www.tvp. info/47359253/koronawirus-nawet-politycy-opozycji-twierdza-ze-dzialacze-kod-powinni-zawiesicprotest-wieszwiecej [Accessed: 5 August 2021] 
TVP Info. (2020m). Premier: Jako jedni z pierwszych przywracamy granice z UE [Prime Minister: We Are One of the First to Restore the Borders with the EU]. March 13. https://www.tvp.info/47114910/premier-ozaostrzeniu-walki-z-koronawirusem-wieszwiecej [Accessed: 5 August 2021]

TVP Info. (2020n). Prezydent: Jeśli koronawirus będzie się rozprzestrzeniał - możliwy zakaz zgromadzeń [President: If the Coronavirus Continues to Spread - Possible Ban on Gatherings]. March 4. https://www. tvp.info/46967952/prezydent-jesli-koronawirus-bedzie-sie-rozprzestrzenial-mozliwy-zakaz-zgromadzen [Accessed: 5 August 2021]

TVP Info. (2020o). Protest przedsiębiorców. Kilku uczestników zatrzymanych; dwóch policjantów rannych [Entrepreneurs' Protest. Several Participants Detained; Two Policemen Injured]. May 8. https://www.tvp. info/47953515/protest-przedsiebiorcow-kilku-uczestnikow-zatrzymanych-dwoch-policjantow-rannych [Accessed: 5 August 2021]

TVP Info. (2020p). Sanepid nałożył kary na uczestników protestów przedsiębiorców [Sanepid Imposed Penalties on the Participants of the Protests of Entrepreneurs]. May 12. https://www.tvp.info/48008267/sanepidnalozyl-kary-pieniezne-na-niektorych-uczestnikow-ubieglotygodniowych-protestow-przedsiebiorcow-wwarszawie-wieszwiecej [Accessed: 5 August 2021]

TVP Info. (2020q). Szef BBN: Nie ma obecnie potrzeby wprowadzania stanu wyjątkowego [BBN Chief: There Is No Need to Introduce a State of Emergency at the Moment]. March 14. https://www.tvp.info/47123963/ pawel-soloch-nie-ma-obecnie-potrzeby-wprowadzania-stanu-wyjatkowego-wieszwiecej] [Accessed: 5 August 2021]

TVP Info. (2020r). Szef MSWiA o wczorajszych działaniach policji: Podstawowym jej zadaniem jest egzekwowanie prawa [The Head of the Ministry of Interior and Administration on Yesterday's Police Activities: Its Primary Task is to Enforce the Law]. May 17. https://www.tvp.info/48089664/mariuszkaminski-podstawowym-jej-zadaniem-jest-egzekwowanie-prawa-wieszwiecej [Accessed: 5 August 2021]

TVP Info. (2020s). Szumowski: Jest szansa na ograniczenie tempa wzrostu zakażeń [Szumowski: There is a Chance to Limit the Growth Rate of Infections]. March 16.

https://www.tvp.info/47140845/minister-zdrowia-lukasz-szumowski-jest-szansa-na-ograniczenie-tempawzrostu-zakazen-koronawirusem-wieszwiecej [Accessed: 5 August 2021]

TVP Info. (2020t). Zakaz wstępu do Lasu Kabackiego? Złożono interpelację [No Entry to the Kabacki Forest? An Interpellation Was Submitted]. March 25. https://www.tvp.info/47266747/warszawa-koronawiruszakaz-wstepu-do-lasu-kabackiego-jest-interpelacja-wieszwiecej [Accessed: 5 August 2021] 